\title{
Literary Competitions Organised by the Ministry of Culture and Arts in 1949-1950 in the Light of Archive Records
}

The resources of the Archives of New Records (AAN) in Warsaw include the heritage of the institutions of People's Republic of Poland (PRL), including those responsible for the development and the shape of culture. This article is based on archival materials left by the Ministry of Culture and Arts (MKiS) that are still fairly unused for research purposes. The studied documents proved to be a motherlode of information on culture and Polish literature (including inedita), offered answers to many questions and helped verify assumptions. Those from the late-1940s and the early-1950s were the most interesting for a researcher of institutional control of speech as they recorded the dramatic process of changing and adjusting culture to the vulgar requirements of Socialist realism.

To begin, I refer to the studies of Janusz Maciejewski on the relation between the authorities and literature. Maciejewski presented three possible models: 1. The authorities are not interested in literature and there is the rule of the market (liberalism); 2. The authorities conduct a certain cultural policy; 3 . The authorities, alienated from society and literature, do not need literature or use it against society ${ }^{1}$. To determine which model applied in Poland in 1949-1950 is not an easy task and, in my opinion, it falls somewhere between the propaganda of the authorities own activities (cultural policy) and their use of literature against society. I will support my opinion with examples drawn from archival records.

In 1949-1950, MKiS announced a series of meticulously arranged literary competitions, the goal of which was to increase the general interest in topics preferred by the authorities and to include the community in the broader process of the social change. They could be considered as a transition between the time of relative creative freedom in $1945-1948^{2}$ and the period of Socialist realism. They

* Prof. dr hab., e-mail: kamilabudrowska@interia.pl; Univesity of Białystok Faculty of Philology, Institute of Polish Philology, 15-420 Białystok, ul. Plac Uniwersytecki 1.

${ }^{1}$ Literatura i władza, Sarnowska-Temeriusz (ed.), Warsaw 1996, pp. 223-265.

${ }^{2}$ Some researchers believe that the cultural structure of 1945-1948 was a revolutionary ending to what was happening to our culture in the late-1930s and during the WWII occupation (c.f. H. Gosk, W kręgu "Kuźnicy”. Dyskusje krytycznoliterackie 1945-1948, Warsaw 1985, p. 27). 
received applications from writers of various political orientations, including those who were not printed in the Stalin era. In addition, some of the proposed works went against the newly accepted directives. Gradually, as the methods of Stalinist literature management grew in strength, disobedient artists, often of great talent, withdrew entirely while those of mediocre skills came to the forefront At the same time the situation of younger artists was quite interesting. They were treated harshly, without any concessions, even when they showed real skills. The all-out nature of the Ministry's intentions is also worth mentioning. It announced competitions for texts in virtually all recipient categories covering a whole host of themes and literary genres, for readers with high cognitive competencies, readers with lower competencies, and for children.

The analysed archival records are rich. In this article, I present only the most interesting matters and the topics that seem worth pursuing.

\section{The $3^{\text {rd }}$ limited mass song competition ${ }^{3}$}

The mass song competition was organised by the Literature Division of the Department of Artistic Works. Its guidelines stated that the themes should include notions directly related to contemporary times, for example, competitive work, the worker-peasant unity, rebuilding ${ }^{4}$. All poems should be 3-4 stanzas long and be easily "musicalised". The deadline for submitting the works was 1 March 1949.

It was a limited competition devised for a selected group of writers. 56 works were submitted, of which 36 were rejected, 8 were were sent for editing and 12 texts received awards and were sent for musical adaptation. The authors who received the awards were: Dobrowolski, Głuszczyński, Jaworski, Kubiak, Lewin, Wirpsza, Woroszylski, Wygodzki, Zagórski - all except Wiktor Woroszylski ${ }^{5}$ and the undeniably outstanding Tadeusz Kubiak, were "stars" of only their era. The real surprise is found in the group of the rejected texts. It included two poems signed by the young Tadeusz Różewicz.

Poems entitled Ręce w kajdanach [Shackled Hands] and Kartka z bloku meldunkowego [A Sheet From the Registration Booklet] are included on two typescript pages. The creases indicate that they were folded and sent by post. The sheets were stamped with the Ministry's stamp bearing the date 31 Jan 1948 (probably a mistake as it should be 1949). They were read and reviewed by all members of the jury (abbreviated signatures on the sheets): Wanda Melcer (Pol-

${ }^{3}$ AAN, MKiS, Department of Artistic Works, Division of Literary Works, ref. no. 498.

${ }^{4}$ Ibidem, 1. 1.

${ }^{5}$ An extended presentation of W. Woroszylski is available in: A. Bikont, J. Szczęsna. Lawina i kamienie. Pisarze wobec komunizmu, Warsaw 2006. 
ish Writers' Union - ZLP), H.G. Michalski (MKiS), Zofia Litte (lection unclear) (MKiS), Zygmunt Mycielski (Polish Composers' Union - ZKP), Aleksander Maliszewski (ZLP). I quote the complete texts:

Ręce w kajdanach

Na kraty spływa jasność

na niewidzące oczy

na beznadzieję godzin

na nocy beznadzieję

Usta otwarte jak rana

i ręce, ręce w kajdanach

i matki będą płakały

nad umęczonym ciałem

Ręce matczyne są słabe

od męki drżące i trwogi

niech słowo stanie się ciałem

a jasność niech stanie się z Bogiem

Toć nasi synkowie też byli

Jak Twój, słabiutki, maleńki

dla Niego dla synka Twojego

i naszych osłoń od męki

A gwiazda w kraty wpleciona

oślepłym oczom jaśnieje

na beznadzieję godzin

na nocy beznadzieję.

Kartka z bloku meldunkowego

Jak pomieścić tęsknotę

w czterech zwrotkach wiersza

i o czym zameldować?

że dziś moja noc pierwsza

że tu stanowisko moje

(stracone... wiem o tym)

że noc się srebrzy gwiezdna

bzy się wiośnią wśród płotów...

tak! na pewno, na pewno

rozpoznałem już wroga:
Shackled hands

Onto bars light falls

on unseeing eyes

on the despair of hours

on the despair of night

Lips spread like an opened wound and hands, shackled hands

and moths will mourn

the tortured body

Mother's hands are weak

shaking with pain and fright

may the word become flesh

and may the light be created with God

As our sons were just the same

As your, weak, tiny

for Him for Your little son

and for ours cover them from pain

And the star weaved between the bars

brightens for the blinded eyes

on the despair of hours

on the despair of night. ${ }^{6}$

\section{A Sheet From the Registration Booklet ${ }^{7}$}

How to fit longing

within just four verses

and what do you report?

that this is my first night

that this is my post

(lost... I know that)

that the night is lit up with stars

lilacs in the fences smell of spring...

yes! for sure, for sure

I have identified the enemy:

\footnotetext{
${ }^{6}$ Ibidem, 1. 34.

${ }^{7}$ The typescript bears handwritten corrections by the author who moved the question mark in the first stanza to the end of the second line.
} 
własne serce tęskniące oczy, usta Twe - Droga... I...już więcej nic nie wiem bo chyba już wszystko Twój - Jedyna - na zawsze (stopień - funkcja - nazwisko) a legenda do szkicu bardzo, bardzo prosta sercem trzeba przeczytać że.... musimy się rozstać. our longing heart eyes, lips of Yours - my Dear... And... I don't know anything else because I think everything else Yours - My Love - forever (rank - position - surname) a legend to a drawing very, very simple must be red through your heart that...we must part ${ }^{8}$.

In early 1949, Tadeusz Różewicz had already authored two collections: Anxiety, a collection of works from 1945-1946 published in Cracow in 1947 by the Przełom publishing house, and The Red Glove, a collection of texts from 1947-1948 published a year later, also in Cracow, but by a more prominent publishing house this time: Książka (later renamed to Książka i Wiedza). None of these collections included the poems submitted for the competition. At this point it is difficult to conclude whether Ręce w kajdanach and Kartka $z$ bloku meldunkowego were included in those collections only to be removed by censorship ${ }^{9}$, but it is possible. In the following collections: Pięć poematów [Five Poems] (1950), Czas, który idzie [Time That Is Coming] (1951), Wiersze i obrazy [Poems and Images] (1952), Wybór wierszy [Selection Of Poems] (1953), Równina [Plateau] (1954), Srebrny kłos [The Silver Ear] (1955), Uśmiechy [Smiles] (1955), could not fit considering their themes.

The mystery of the origins of those poems only becomes clear when one reaches for Echa leśne [Forest Echoes]. The writer's début collection was created in 1943 as a bulletin, affixed to a division notice board, entitled "A voice from a bush". It was later typed and published by the underground in 1944. Its first postWWII publication occurred 40 years later.

In the 1985 afterword Tomasz Jodełka-Burzecki emphasised the authenticity of the document, the reliability of the testimony and the superb quality of the artistic form:

The entire collection is a simple soldier's report on the situation of a Home Army troop, which in the summer of 1943 Tadeusz Różewicz was a member of. The young author captured in the field the reality of partisan life. (...) Cadet Satyr is a man of

${ }^{8}$ Ibidem, p. 35.

${ }^{9}$ GUKPPiW (Main Office of Control of Press, Publications and Shows) material regarding censorship of poetry before 1948 has survived in a fragmented form (cf. K. Budrowska, Literatura i pisarze wobec cenzury PRL. 1948-1958, Białystok 2009). 
few words: even poems are basically army reports, though a practised Polish reader will not easily skip the fervent prayer for the Unknown Soldier of the Polish Underground, a brother in arms, entitled $O$ ciebie się modle [I Pray For You] ${ }^{10}$.

The collection includes a few quotes from Słowacki, short stories as well as fraszkas (a type of epigrams) and poems: $O$ ciebie się modle [I Pray For You], Ręce $w$ kajdanach, Kartka z bloku meldunkowego (signed Janusz Różewicz), Dla żolnierza tułacza [For the Vagrant Soldier] (signed Z.S.) The Wspótcześni polscy pisarze i badacze literatury [Contemporary Polish Writers And Literary Researchers] dictionary states that the poems Kartka z bloku meldunkowego and Dla żotnierza tułacza are poems by Janusz Różewicz, the poet's late brother ${ }^{11}$.

The poem Kartka $z$ bloku meldunkowego submitted by Różewicz for the mass song competition turns out not to be his! In addition, the contemporary themes expected by MKiS that included notions directly related to contemporary times, competitive work, the worker-peasant unity, and rebuilding were by no means fulfilled by the texts submitted by Różewicz. It is difficult to say whether it was just an oversight or an intentional move by the author invited to participate in the competition. Nonetheless, religious poems with wartime themes must have been quite shocking for the reviewers. Bear in mind that those poems were written by Home Army soldiers, which shows how complicated post-WWII times and, in turn, literature were.

Interestingly, in 1989, Tadeusz Różewicz published letters from editors refusing to print his texts, yet there is no mention of the rejection of the poems submitted for the 1949 competition $^{12}$.

\section{Lyrics competition (1950) ${ }^{13}$}

This competition, just as the one previously discussed, was organised by the Literature Division of the Department of Artistic Works. No report with competition guidelines survived, only the literary texts. Considering their uniform Socialist realism themes, one might assume, though, that the rules were announced somewhere (a ZLP meeting, maybe in one of the journals?) The file includes manuscripts of the works as well as their typed versions (probably by MKiS).

${ }^{10}$ T. Różewicz, Echa leśne, Warsaw 1985, p. 71.

${ }^{11}$ Współcześni polscy pisarze i badacze literatury. Stownik biobibliograficzny. J. Czachowska, A. Szałagan (eds.), vol. 7, Warsaw 2001, p. 91.

12 T. Różewicz, Różne oblicza cenzury, “Odra” 1989, issue 4, pp. 52-56.

${ }^{13}$ AAN, MKiS, Department of Artistic Works, Division of Literary Works, ref. no. 506, no pagination. 
Poems which were to be supplemented with music are marked with emblems and at the bottom, the manuscripts include the author's surname, address, and sometimes occupation.

Only one well-known poet applied: Wiktor Woroszylski with a poem entitled Wiatr pokoju [Wind Of Peace]. Underneath some texts, there appear notes by reviewers, e.g.: "to be established with the author, rework the first verse".

A considerable value was assigned to the possibility of musicalisation. Some texts were rejected only because they were "not musical enough". The intention to use the poems in combination with music seems a carefully devised method of propagating the poems: it is easier to reach the mass audience with texts which are short, melodious, and rhymed than with blank verse with a complicated structure. Therefore, it is clear that the authorities encouraged artists to create those simpler forms. A proof that the strategy bore desired results is seen in the Stownik realizmu socjalistycznego [Dictionary of Socialist realism] where the entry "Konwencje i gatunki literackie" [Conventions and literary genres] stated that in 1949-1955 lyric poetry was made inferior and the value of epic poetry was boosted ${ }^{14}$.

The unlimited form of the competition and simple themes associated with everyday life were supposed to help find new talent (notes: "to be established with the author"), and enrich the community of writers by adding people originating from the working-class or peasantry.

\section{Sports poem competition $(\mathbf{1 9 5 0})^{15}$}

The competition was announced by the Department of Artistic Works of MKiS and the Division of Propaganda and Publications of the Chief Physical Culture Office. The expected poems were required to be used as lyrics. The themes were to consider the role and the tasks of sports in the People's Republic of Poland. The deadline for submitting the works was set to 1 Oct 1950. For the first stage, 273 works were submitted out of which only 3 received awards and 4 distinctions. There were no well-known personalities among the authors. The second stage of the competition consisted of the musicalisation of the works ${ }^{16}$. The typescripts of the poems included reviewer notes regarding text quality, they were graded and the highest grade was assigned to a poem entitled Marsz sportowy [Sports march] (Lighthouse emblem, no surname of its author).

\footnotetext{
${ }^{14}$ Stownik realizmu socjalistycznego, Z. Łapiński, W. Tomasik (eds.), Cracow 2004, pp. 108-112.

${ }^{15}$ AAN, MKiS, Department of Artistic Works, Division of Literary Works, ref. no. 503.

${ }^{16}$ AAN, MKiS, Department of Artistic Works, Division of Literary Works, ref. no. 502.
} 
At this point two issues are worth mentioning. First, the sports poem expected by the jury was not supposed to exist on its own, but rather become an element of a verbal and musical composition. Thus, once again the notion of propagating lyrical poetry through music and the subordination of text to music appeared. Secondly, it is possible that it was inspired by the international Literary Competition at the Summer Olympics.

During the $14^{\text {th }}$ Summer Olympic Games in London in 1948 a contemporary arts competition was held which covered many areas including literature. Each nation could submit 9 literary texts, 3 in each category (poetry, drama, prose) featuring sports themes. Compositions of up to 20,000 words had to be submitted by 27 Mar 1948 in their original form with an accompanying summary in one of the official languages.

Before being sent to the United Kingdom, Polish texts were pre-screened by MKiS. 155 envelopes with works were submitted in total, 55 works were identified as meeting the competition criteria and only 2 were sent to London. No first prizes were awarded in drama and prose while in poetry the first prize was awarded to Jarosław Iwaszkiewicz for Ody olimpijskie [Olympic Odes].

The justification statement read:

The inspector (Kazimierz Wyka - K.B.) motioned to award the first prize to the author of Ody olimpijskie ("Cypress and laurel" emblem) underlining its poetic qualities in its discrete affinity to the works of French literature (good rhetoric, flow, and clarity) and the comprehensive presentation of the attitude of contemporary Poland towards culture and historical events. The reading of Ode $I V$ further convinced the present members of the legitimacy of the assessment. Aleksander Wat highlighted the desired feature of the poem's easy "translatability" to other languages ${ }^{17}$.

Ody olimpijskie received in London a diploma of recognition (Grażyna Bacewicz for her musical composition entitled Cantata olimpijska [Olympic cantata] was also recognised). They were published in Paris translated into French in 1949, and in Poland - a year earlier ${ }^{18}$.

Iwaszkiewicz's success and the interest in the Olympic competition (155 works submitted!) was not overlooked by the Ministry. That might had been the source of the idea for a new sports poem competition. It did not, however, had such spectacular results.

${ }^{17}$ AAN, MKiS, Department of Artistic Works, Division of Literary Works, ref. no. 500, 1. 4.

${ }^{18}$ Wspótcześni polscy pisarze..., vol. 3, p. 322. 


\section{Serial novel competition $(\mathbf{1 9 4 9 - 1 9 5 0 )})^{19}$}

In late 1949, MKiS established a Commission for Serial Fiction, the goal of which was to "promote entering the area of serial fiction among renowned writers who had previously avoided this type of works" and initiate serials. The creation of this advisory entity was a result of a visible decline in the level of these works printed in the press. It is worth noting that after WWII such a form of publication was widely popular among the readers considering the still low saturation of the book market ${ }^{20}$. During the first meeting of the Commission held on 20 June 1949 negative voices were raised on the poor condition of such texts and the fact that serials were mainly translations ${ }^{21}$. Jarosław Iwaszkiewicz, being the chairman of the ZLP, was a member of the Commission.

A limited competition for novels appropriate for a serial was announced in December $1949^{22}$. A list of writers who were invited to participate in it indicates that the Ministry intended to involve renowned writers; there was a blatant reference to "acquiring writers". By the first deadline, the following writers applied: Kazimierz Koźniewski with an outline of Piatki z ulicy Barskiej [The Five from Barska St.], Kornel Filipowicz with a Baltic fisherman's log, Adam Bahdaj with Droga do kraju [Road back to the country] (unrecorded text), Irena Krzywicka with a proposal for a novel about the issues of women's labour, Magdalena Samozwaniec with a completed Czy pani mieszka sama? [Madam, do you live alone?], which did not satisfy the expectations of the Commission. On 13 Feb 1949, an additional list of names was devised which included artists whose involvement was particularly important for the Ministry. The 19 selected persons included: Tadeusz Breza, Jerzy Andrzejewski, Mieczysława Buczkówna and Stanisław Piętak ${ }^{23}$. Interesting, such well-known writers as Andrzejewski, whose fame after the success of Ashes and Diamonds (first published as a serial) was at its peak, appeared side by side with Buczkówna, only debuting with her collection of poems entitled Rozstania [Partings]. The origins of the idea that a poet could write a good serial remains unclear.

Between November 1949 and January 195038 novels and 4 layouts were analysed in view of their possible publication. It should be stressed that not all texts

${ }^{19}$ AAN, MKiS, Department of Artistic Works, Division of Literary Works, ref. no. 487.

${ }^{20}$ H. Gosk, op. cit.

${ }^{21}$ AAN, MKiS, Department of Artistic Works, Division of Literary Works, ref. no. 487, 1. 26.

${ }^{22}$ I have previously written about the competition: K. Budrowska, Tajne pismo cenzury. "Biuletyn Informacyjno-Instrukcyjny" w latach 1952-1955, in: Komunikowanie się Polaków w latach 1944-1989, K. Stępnik, M. Rajewski (eds.), p. 57 and the following; it was also referenced by J.M. Bates in the context of Koźniewski's novel entitled Piatka z ulicy Barskiej (cf. J.M. Bates, Cenzura w epoce stalinowskiej, "Teksty Drugie” 2000, issue 1-2, pp. 114-117).

${ }^{23}$ AAN, MKiS, Department of Artistic Works, Division of Literary Works, ref. no. 487, 1. 118. 
were written specifically for the competition. Some were already completed texts which the authors decided to submit as fit for such a publication. Uczta Baltazara received the highest evaluation. The report read: "It is the view of the reviewers that the novel entitled Uczta Baltazara can become a breakthrough moment in the artistic life of Breza, who is today one of the leading writers" 24 . It was printed in the Świat journal in 1951-1952 (issues 1-23 and 1-6) ${ }^{25}$, yet bibliographies fail to record the fact that it was submitted for the competition.

The fortunes of Koźniewski's text were also interesting. According to John M. Bates' findings Koźniewski reworked the layout several times at the request of the competition committee introducing ideological and compositional corrections; then, censorship intervened into the completed text ${ }^{26}$. The novel was eventually published in 1952 and in the same year it was recognised with the $3^{\text {rd }}$ degree National Artistic Award while in 1954 it became the basis of a film script ${ }^{27}$. Regardless of its undeniable success it was never published as a serial.

Andrzejewski, of whom the authorities expected much, did not submit anything for the competition. In general, between 1949 and 1955 he did not produce any valuable text. Eventually in 1957 he published in instalments in Przeglad Kulturalny (issues 12-17) the interesting Ciemności kryja ziemię [Darkness Covers The Land]. But that was a completely different time and a completely different text, which would had probably never be approved by the Commission for Serial Fiction.

\section{Literary competition for developing a Polish folk tale (1949-1950 $)^{28}$}

Fable themes were prepared by the Ministry with the help of Prof. Julian Krzyżanowski: Jak Bartek zostat lekarzem [When Bartek became a doctor], O chtopcu, jego kotku, piesku i lewku [About a boy, his cat, dog and lion], Nadzwyczajni pomocnicy [Extraordinary helpers], and Żona szuka utraconego męża [Wife looking for her lost husband] ${ }^{29}$. Fantastic elements should be removed from tales for children aged 8-10 and instead replaced with folk elements.

As many as 80 people responded to the competition. The first stage, however, did not offer satisfactory results. In the post-meeting report the jury even

\footnotetext{
${ }^{24}$ AAN, MKiS, Department of Artistic Works, Division of Literary Works, ref. no. 487, 1. 133.

${ }^{25}$ Współcześni polscy pisarze..., vol. 1, p. 275.

${ }^{26}$ J.M. Bates. op. cit., pp. 114-115.

${ }^{27}$ Wspótcześni polscy pisarze..., vol. 4, p. 355.

${ }^{28}$ AAN, MKiS, Department of Artistic Works, Division of Literary Works, ref. no. 501.

${ }^{29}$ This was discussed in detail in: K. Budrowska, Literatura i pisarze wobec cenzury..., p. 213-214.
} 
stated scornfully that "everyone thinks that anyone can write stories for children". Therefore, in 1950, a second stage of the competition was held, this time in a limited form, issuing invitations to six female authors of texts for children: Hanna Januszewska, Irena Jurgielewiczowa, Mieczysława Buczkówna (since 1949 publishing in children's magazines), Wanda Grodzieńska, Janina Porazińska and the author duo - Anna Milska and Wanda Markowska. All the authors responded to the competition and Hanna Januszewska was announced its winner. Her collection entitled Baśnie polskie [Polish Fables] was published by the Czytelnik publishing house in 1952.

\section{Limited competition for revolution and socially-themed lyrics for children $(\mathbf{1 9 5 0})^{30}$}

In the case of this competition the previous mistakes were avoided thus proposing a limited form ${ }^{31} .23$ writers were invited to participate, again including Jan Brzechwa, Julian Tuwim and Januszewska. The task to create revolutionary and socially-themed lyrics for pre-school children proved difficult. Only 10 authors participated in the competition. $1^{\text {st }}$ prize was not awarded and the $2^{\text {nd }}$ prize was divided between Maria Kownacka for her Ochocza drużynka [Eager Crew] and Karol Szpalski for his Piosenka 1-Majowa [May ${ }^{\text {st }}$ Song].

The archival records include typescripts of the texts of all the competition participants, only 21 works in total.

In refererence to both children's text competitions, it is worth noticing their clear propagandist nature. The goal was to create works different from traditionally understood children's literature. Researchers of Socialist realist children's literature have indicated the switch to specific themes, saturating the texts with an air of ideological zeal, and their gradual secularisation. What is interesting, they highlight in the case of poetry the fact that adult literature was imitating children's literature, not the other way around. That was required by the convention of expression: placing a strong emphasis on its communicative nature and simplicity $^{32}$. Mariusz Zawodniak wrote:

And so, the post-WWII years shall probably remain the only period in the history of literature when the role and status of children's and young adult literature has been virtually equated to that of adult literature. Socialist realism in particular did

\footnotetext{
${ }^{30}$ AAN, MKiS, Department of Artistic Works, Division of Literary Works, ref. no. 505.

${ }^{31}$ In detail: K. Budrowska, Literatura i pisarze wobec cenzury..., p. 206.

32 Z. Jarosiński, Nadwiślański socrealizm, Warsaw 1999, pp. 277-297.
} 
not differentiate literary works in this respect; on the contrary, it placed even works primarily for younger audiences within current events, thus transforming them into literary creations which became well-known and important, which received awards, and which even became role models for other (...) One example: the popularity of Piątka z ulicy Barskiej by Kazimierz Koźniewski, a success based on the previously released Soviet productions $(\ldots)^{33}$.

NB, Piatka z ulicy Barskiej was written for a competition organised by the Ministry of Culture and Arts.

The discussed features of Socialist realist literature for young audiences are clearly visible in texts produced for Ministry competitions. Moreover, one can also see the methods which were used to achieve the required results.

Let us return to the issue of the relations between the authorities and literature in Poland in 1949-1950. Using the analysed archival records one has a unique opportunity to look into the mechanisms of cultural change. To see not only the effects but also the process of introducing or even creating new guidelines. MKiS documents constitute operational material, i.e. confidential. That is why they include directly stated opinions, not found anywhere in press releases of that time, revealing the brutal reality. One such example was the competition for a folk tale: when it failed to deliver expected results (even though 80 authors responded), the authorities simply changed the rules.

In view of the discussed archival records, the official cultural policy acquired a rather different tone: a system of incentives, large prizes, attractive themes, considerable diversity and number of competitions on the one hand and the rejection of very good texts which did not meet political expectations, the manipulation of the rules, multiple corrections to final layouts and texts on the other. Many writers were perfectly aware of the ambiguous nature of the Ministry's offer and did not accept invitations. Top writers could afford this without considerably hurting their careers but for younger writers, those taking their first steps in the area of literature, to reject such offers was equivalent to non-existence. Therefore, that resulted in a negative selection and destroying the authors' potential. Mind you, in the mass song competition, Tadeusz Różewicz was vanquished by, i.a. Dobrowolski, Głuszczyński or Jaworski.

Through the competitions the authorities manipulated not only the authors but also the audience. A considerable decrease in the expectations towards texts (short, simple, for a mass audience, in instalments) directly translated into decreased expectations on the part of the audience. People were supposed to enjoy uncomplicated works which preferably can be easily "musicalised". The notion

${ }^{33}$ M. Zawodniak, Dziesięciolecie 1945-1955 (historia literatury i przedmioty badania), in: PRL. Świat (nie)przedstawiony, A. Czyżak, J. Galant, M. Jaworski (eds.), Poznań 2010, p. 178. 
of a society with a passion for singing in the late-1940s and early-1950s could be considered amusing if it was not so bitter, yet, as we know, the enforced optimism masked difficult political and social issues. If, as Jerzy Drygalski and Jacek Kwaśniewski maintain, the intensity of propaganda should be measured not based on the intensity of persuasion but on the intensity of the information blockade ${ }^{34}$, one should ask what issues the decision-makers who organise the competitions for a sports song, a revolution song or a contemporary serial were trying to conceal (Socialist realist, as we know from the records). Undoubtedly political terror, lack of any civil rights, hunger, destitution, terrible living conditions in the cities and in the countryside.

However, trivial themes were used mainly to conceal one single theme central to the Polish $20^{\text {th }}$ century literature: the experiences of the Second World War and the occupation. We know that the efforts were successful in 1949-1955. But that is something to be pursued in another paper.

\section{Bibliography}

AAN, MKiS, Department of Artistic Works, Division of Literary Works, ref. no. 487, 498, 500, 501, 502, 503, 505, 506,

Bikont Anna, Szczęsna Joanna, Lawina i kamienie. Pisarze wobec komunizmu, Prószynski i S-ka, Warsaw 2006.

Bates John M., Cenzura w epoce stalinowskiej, “Teksty Drugie” 2000, No. 1/2, pp. 114-117.

Budrowska Kamila, Literatura i pisarze wobec cenzury PRL. 1948-1958, Wydawnictwo Uniwersytetu w Białymstoku, Białystok 2009.

Budrowska Kamila, Tajne pismo cenzury. "Biuletyn Informacyjno - Instrukcyjny” w latach 1952-1955, in: Komunikowanie się Polaków w latach 1944-1989, K. Stępnik, M. Rajewski (eds.), Wydawnictwo UMSC, Lublin 2011, pp. 51-61.

Gosk Hanna, W kręgu "Kuźnicy”. Dyskusje krytycznoliterackie 1945-1948, Państwowe Wydawnictwo Naukowe, Warsaw 1985.

Jarosiński Zbigniew, Nadwiślański socrealizm, Wydawnictwo IBL PAN, Warsaw 1999.

Literatura i władza, E. Sarnowska-Temeriusz (ed.), Wydawnictwo IBL PAN, Warsaw 1996.

Różewicz Tadeusz, Echa leśne, Państwowy Instytut Wydawniczy, Warsaw 1985.

Różewicz Tadeusz, Różne oblicza cenzury, “Odra” 1989, No 4, pp. 52-56.

Stownik realizmu socjalistycznego, Z. Łapiński, W. Tomasik (eds.), Universitas, Cracow 2004.

Współcześni polscy pisarze i badacze literatury. Słownik biobibliograficzny, J. Czachowska, A. Szałagan (eds.), vol. 1-10, Wydawnictwa Szkolne i Pedagogiczne, Warsaw 1994-2007.

Zawodniak Mariusz, Dziesięciolecie 1945-1955 (historia literatury i przedmioty badania), in: PRL. Świat (nie)przedstawiony, A. Czyżak, J. Galant, M. Jaworski (eds.), Wydawnictwo Poznańskie Studia Polonistyczne, Poznań 2010, pp. 173-185.

\footnotetext{
${ }^{34}$ J. Drygalski, J. Kwaśniewski. (Nie)realny socjalizm, Warsaw, 1992, p. 261.
} 


\title{
Kamila Budrowska
}

\section{Literary Competitions Organised by the Ministry of Culture and Arts in 1949-1950 in the Light of Archive Records}

\begin{abstract}
(Summary)
The subject of this paper are these literary competitions organized by Ministry of Culture and Arts in the late 1940s and early 1950s. Analysys of the materials from archivesenabled to tackle the issues: these competitions are one of the many aspect of stalinism offensive. Competitions encouraged writers for moving problems of socialist realism, they enforced artists for submission in accordance with Government of country.In article characterized six competitions. Most curious was "Third competition on mass song", in which took part important writer Tadeusz Różewicz.

Keywords: literary competitions, Ministry of Culture and Arts, censorship after 1945, literary life after 1945
\end{abstract}

